\title{
Examination of Microplastic Particles in Reef Fish Food in Ternate Island Waters, Indonesia
}

\author{
Mimien Henie Irawati Al Muhdhar ${ }^{{ }^{*}}$, I Wayan Sumberartha ${ }^{1}$, Zainudin \\ Hassan $^{2}$, Muhammad Shalahuddin Rahmansyah ${ }^{3}$, M. Nasir Tamalene ${ }^{4}$ \\ ${ }^{1}$ Faculty of Mathematics and Natural Science, Universitas Negeri Malang, Box 65139 Kota Malang JawaTimur-Indonesia; ${ }^{2}$ Faculty Sains \\ Sosial dan Kemanusiaan University Teknology Malaysia. Box 81310 Skudai Johor Bahru-Malaysia; ${ }^{3}$ Sekolah Tinggi Teknik Industri Turen \\ Malang, Box 65175Turen Kabupaten Malang- Indonesia; ${ }^{4}$ Biology Universitas Khairun Jl. Bandara Babullah Kampus 1 Akehuda Box \\ 97728. Ternate, Indonesia.
}

Received: July 20, 2020; Revised: November 27, 2020; Accepted: January 12, 2021

\begin{abstract}
Microplastics are pollutants, such as debris from human activities that contaminate several marine biotas and the environment. This research examined the occurrence of microplastic particles in the fish digestive tract in Ternate Island waters, Indonesia. The visual method carried out in the laboratory using a stereo microscope with a magnification of up to 40x was used to identify microplastics in the intestines and stomachs of fish. After observation, the pollutants were systematically counted in the range of $0.3-5 \mathrm{~mm}$ based on color, size, number, and shape. They were also classified into: 1 ) fragments, 2) films, 3) lines/fibers, 4) foams, and 5) pellets categories. Furthermore, six types of fishes including Epinephelus Fuscogutattus, Epinephelus coioides, Epinephelus suillus, Siganus canaliculatus, Synanceia, and Scarus Psittacus were collected from four sites, Kasturian, Kampung Makasar, Mangga dua, and Kalumata between August and September 2019. The results showed 183, represented by $83.18 \%$, of the 220 reef fish individuals studied have ingested plastics. Moreover, a total of 594 plastic particles were found in the digestive tract of which $47.81 \%$ were fragments, $38.22 \%$ films, $2.69 \%$ foams, $2.36 \%$ fibers, $7.41 \%$ line, and $1.52 \%$ of 1.8 to $5 \mathrm{~mm}$ sized pellets. The color distribution in all locations include $46.80 \%$ transparent, $32.15 \%$ black, $5.56 \%$ pink, $6.06 \%$ yellow, $5.22 \%$ blue, and $4.21 \%$ red. The findings of this study provide the first evidence of microplastic contamination in reef fishes of the Ternate Island waters littoral zone Indonesia.
\end{abstract}

Keywords: Microplastic Particles, Reef Fish Food, Ternate Island Waters, Indonesia

\section{Introduction}

The increase in global plastic production has led to the pollution of oceans with 4.8 to 12.7 million metric tons (MMT) of plastic wastes, and Indonesia was ranked second among the countries with the highest contribution with 0.48-1.29 MMT (Jambeck et al., 2015). Microplastics are generally defined as plastics with a diameter less than 5 $\mathrm{mm}$ formed through the decomposition of micro-plastics or abrasive materials used in cosmetics and detonation media (Barnes et al., 2009). They have the potential to cause damage and contaminate the marine ecosystem due to the continuous increase in the global production of plastic wastes (Barnes et al., 2009); (Jundong Wang et al., 2016). Microplastics also cause physical and toxicological damage to the marine organism (Law \& Thompson, 2014) and threat to marine biota due to their small size which makes them biologically available for organisms in all food networks (Betts, 2008; Wick et al., 2013; Bergmann et al., 2015).

Marine fauna in the ocean such as marine invertebrates (Murray \& Cowie, 2011), fishes (Boerger et al., 2010; Romeo et al., 2015; Davison \& Asch, 2011), Zooplankton (Cole et al., 2013), Crustaceans (Goldstein \& Goodwin, 2013) sea birds (Ryan et al., 2009), and mammals (Eriksson \& Burton, 2003) ingest microplastics in the water, and this has negative effects on their health. The consumption of these particles reduces the ecophysiological function of the organisms thereby causing physical injuries and physiological stress (Rochman et al., 2013). In addition, microplastics are prone to contamination by toxic organic pollutants in water (Bakir et al., 2014; Rowland et al., 2016), which after being ingested enter the food chain to cause bio-magnification (Farrell \& Nelson, 2013; Setälä et al., 2016).

The contamination of waters areas by microplastics has been reported in Cilacap Gulf with 2.5

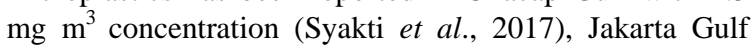
(Manalu et al., 2017), and small islands in Bintan Regency, Kepulauan Riau Province (Syakti et al., 2018). The particles currently existing in the Java sea are assumed to have originated from the South China Sea and the Pacific Ocean (Handyman et al., 2019). Meanwhile, the microplastics found in the Spermonde Islands of Makassar Gulf were contaminating seagrass beds (Tahir et al., 2019) and Muara Jagir of Surabaya City (Firdaus et al., 2020). The fishes from Trichiurus sp. and Johnius sp. were also reported to have ingested microplastics in Pangandaran Gulf (Ismail et al., 2019) while other pollutions associated with this material have also been discovered in the Karimunjawa national park waters (Lie et al., 2018).

Even though the presence of microplastics in the ocean is a serious threat to marine organism, residents of Ternate 
Island of North Maluku Province-Indonesia have a habit of dumping plastic wastes into the sea. Previous research showed the Ternate Island sea is dominated by seven plastic types and these are 1) bottles, 2) bags, 3) glasses, 4) packages, 5) spoons, 6) toys, and 7) straps without any focus on microplastic pollution. This present research was, therefore, conducted to fill this gap by examining the presence of microplastic particles in the reef fish digestive tract in the littoral zone of Ternate Island waters, i.e Katurian, Kampung Makassar, Mangga Dua, and Kalumata.

\section{Method}

\subsection{Study Area}

The research was conducted at Ternate Island, Maluku Utara Province shown in Figure. 1 which was selected due to the fact that $80 \%$ of its area is made of the ocean and the residents' activities are predominantly centered on the waters.

\subsection{Tools}

The tools used include gloves, straps, scissors, ropes, plastic containers, a small shovel, beakers, tweezers, nails, glass objects, Petri dishes, fishing nets, stereo microscopes, and pencils Jabeen et al. (2017).

\subsection{Microplastics Separation Procedures}

The saturated salt solution used to separate microplastics and non-microplastics through the floatation technique was prepared at $1.2-1.5 \mathrm{~g} / \mathrm{mL}$ concentration. The process involved the addition of approximately $850 \mathrm{~mL}$ $\mathrm{NaCl}$ into a sample bottle and left for 10-15 minutes after which the solution was filtered using a Wattman filter paper. This was followed by the placement of the filter paper in a covered petri dish to observe microplastic particles using a microscope. The procedure was in line with the method used by Li et al. (2016); Jabeen et al. (2017).

\subsection{Microplastic Visual Identification}

A visual method was used to identify microplastics in fish intestines and stomach. This involved the observation of the particles visually at the laboratory using a stereo microscope with magnification up to $40 \mathrm{x}$ after which they were calculated systematically in a range of $0.3-5 \mathrm{~mm}$ based on color, size, number, and shape and further classified based on five categories which are 1) fragment, 2) film, 3) line/fiber, 4) foam and 5) pellet (Hidalgo-Ruz et al., 2012; Free et al., 2014).

\subsection{Data Analysis}

Microplastic amounts are presented as the mean values. Microsoft Excel software was used to calculate the percentage value of microplastic density data according to type and fish.

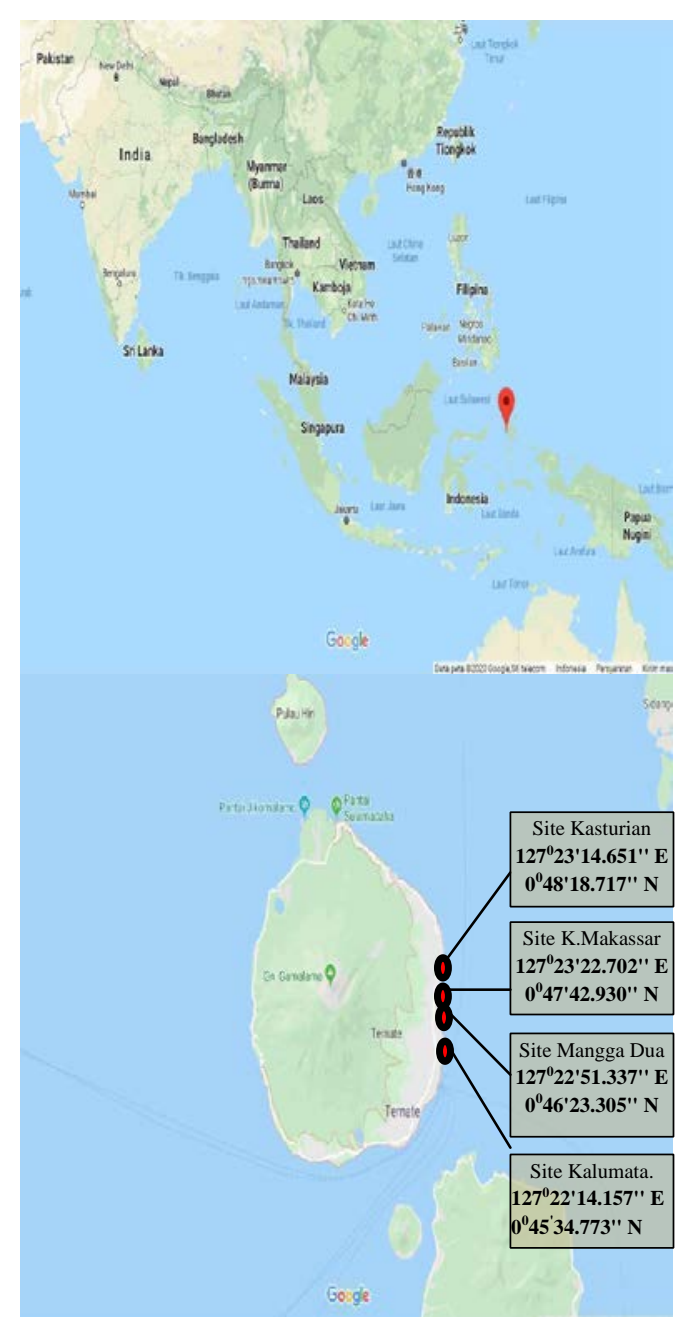

Figure 2. Sample Location (Source:

https://www.google.com/maps/; Access March 2020)

\section{Results and Discussion}

\subsection{Microplastic abundance in reef fishes}

The results showed 183 individuals, represented by $83.18 \%$, of the 220 reef fishes examined had ingested plastics as shown in Table 1. The six types of fish studied include Epinephelus Fuscogutattus, E. coioides, E. suillus, Siganus canaliculatus, Synanceia, and Scarus Psittacus. Moreover, a total of 594 plastic particles were found in the digestive tract out of which $47.81 \%$ were fragment, $38.22 \%$ film, 2. $69 \%$ foam, $2.36 \%$ fiber, $7.41 \%$ was line, and $1.52 \%$ pellet ranged between 1.8 and $5 \mathrm{~mm}$ as presented in Figure. 3. 
Table 1. The Number of Reef Fishes that have Ingested the Microplastic Waste in Ternate Island Waters

\begin{tabular}{|c|c|c|c|c|c|c|c|c|c|}
\hline \multirow{2}{*}{ Fish Species } & \multirow{2}{*}{$\begin{array}{l}\text { Number of } \\
\text { Samples }\end{array}$} & \multirow{2}{*}{$\begin{array}{l}\text { Number of Fish that } \\
\text { Ingested Microplastics }\end{array}$} & \multicolumn{6}{|c|}{ Number of Microplastics based on Shape } & \multirow{2}{*}{ Total } \\
\hline & & & Fragment & Film & Foam & Fiber & Line & Pellet & \\
\hline Epinephelus fuscogutattus & 29 & 23 & 37 & 32 & 3 & 5 & 12 & 0 & 89 \\
\hline Epinephelus coioides & 36 & 31 & 64 & 24 & 0 & 5 & 2 & 0 & 95 \\
\hline Epinephelus suillus & 65 & 56 & 60 & 14 & 3 & 2 & 17 & 2 & 98 \\
\hline Siganus canaliculatus & 47 & 35 & 43 & 67 & 2 & 2 & 1 & 1 & 116 \\
\hline Synanceia & 27 & 27 & 62 & 78 & 4 & 0 & 12 & 4 & 160 \\
\hline \multirow[t]{2}{*}{ Scarus Psittacus } & 16 & 11 & 18 & 12 & 4 & 0 & 0 & 2 & 36 \\
\hline & 220 & 183 & 284 & 227 & 16 & 14 & 44 & 9 & 594 \\
\hline
\end{tabular}

Based on the types of fish, Synanceia was found to have ingested $26.94 \%$ and S.canaliculatus $19.53 \%$. Moreover, 89 plastic particles were discovered in the digestive tract of E. fuscogutattus, 95 in E. coioides, 98 in E. suillus, 116 in S. canaliculatus, 160 in Synanceia, and 36 in S.Psittacus as shown in Table 1 and Figure. 2.

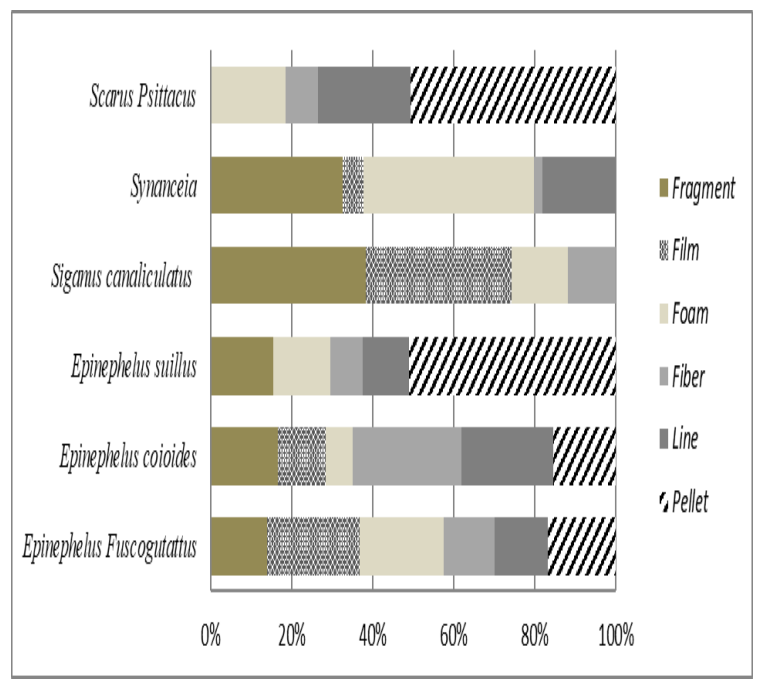

Figure. 2. Percentage of microplastic particles ingested by fish

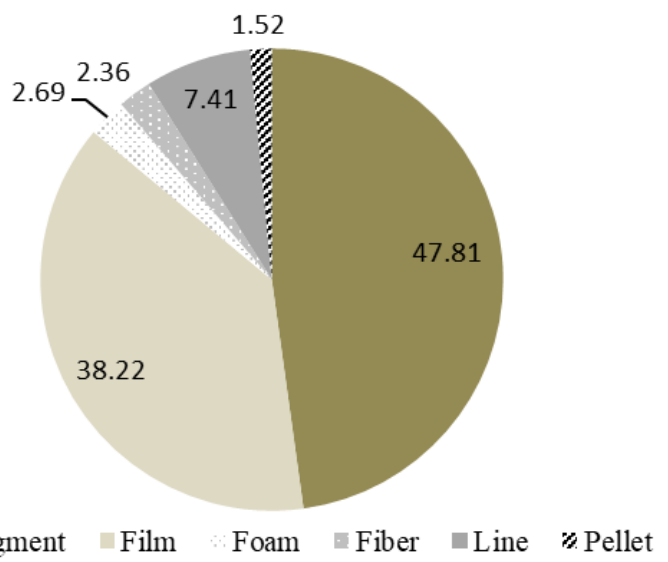

Figure 3. Total Percentage of Microplastic Type ingested by fish

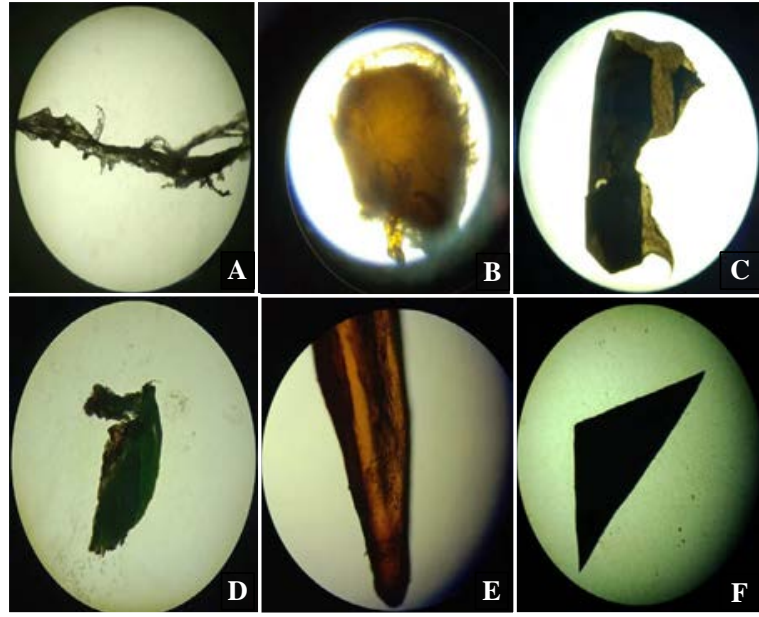

Figure. 4. The Stereo shape of microplastic; (A) Pellet (B) foam, C) film, (D) Fiber, (E) line, (F) fragment

The colors of microplastic particles ingested by $E$. fuscogutattus fish were found to be transparent with $53.93 \%$ followed by black with $26.97 \%$, pink with $13.48 \%$, yellow with $3.37 \%$, and blue and red with $1.12 \%$. Meanwhile, E. coioides ingested $33.68 \%$ transparent, $28.42 \%$ black, $13.68 \%$ blue, $15.79 \%$ red, $6.32 \%$ yellow, and $2.11 \%$ pink. E. suillus had $57.14 \%$ transparent, $34.69 \%$ black, $2.04 \%$ pink, $1.02 \%$ blue, 3.06\% yellow, and $2.04 \%$ red. Moreover, S. canaliculatus ingested 58.62\% transparent, 36.21\% black, $1.72 \%$ pink, $2.59 \%$ blue, $0.86 \%$ yellow, and no red color was recorded. In Synanceia, 41.88\% transparent, $25.63 \%$ black, $8.13 \%$ pink, $7.50 \%$ blue, $14.38 \%$ yellow, and $2.50 \%$ red were recorded. Finally, S. Psittacus was recorded to have $19.44 \%$ transparent, $63.89 \%$ black, 5.56\% pink, $2.78 \%$ blue, and $8.33 \%$ red without any yellow particle as shown in Figure. 3. The total color distribution of microplastics ingested by the reef fishes in all sites includes $46.80 \%$ transparent, $32.15 \%$ black, $5.56 \%$ pink, $6.06 \%$ yellow, $5.22 \%$ blue, and 4.21\% red as shown in Figure. 4. 


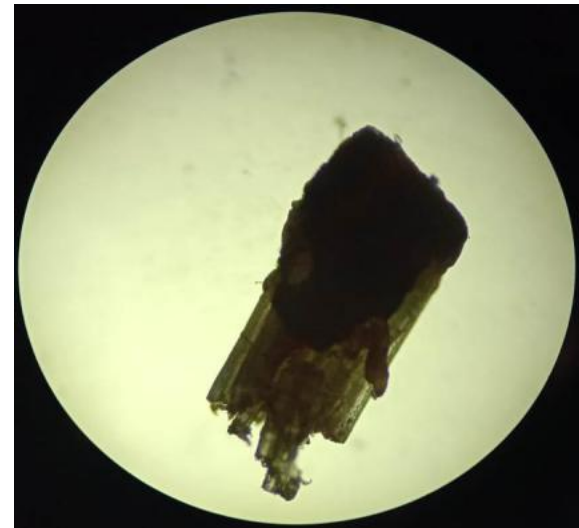

Figure. 5. Color distribution of microplastics ingested by five types of fish

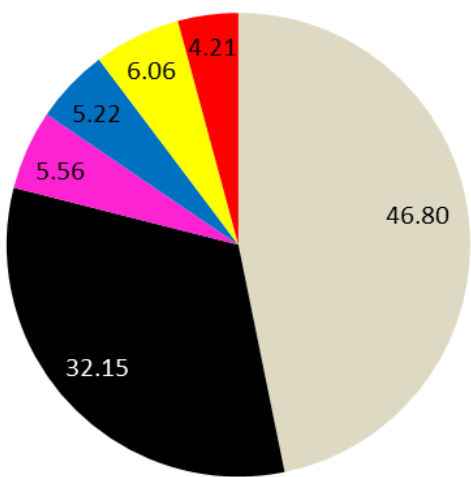

Transparent घBlack $\square$ Pink $\square$ Blue Yellow $\square$ Red

Figure. 6. Color distribution of microplastics ingested by fish in all locations

\section{Discussions}

The result showed the microplastic particles found in the digestive organelle and stomach of reef fishes in the Ternate Island waters littoral zone were likely from several plastics dumped into the ocean by humans and later consumed by the fishes, which later caused a disturbance in their food network. This is in line with the report that the presence of microplastics in sediments and seawater is caused by human activities such as waste disposal (Ng \& Obbard, 2006). It has also been discovered that microplastics are not only in the coastal areas but also in the deepest reach of the ocean, East Atlantic Sea, Asia Sea, and the North Pole (Van Cauwenberghe et al., 2013; Lusher et al., 2014; Ivleva et al., 2017; Wagner \& Lambert, 2018; Jun Wang et al., 2019; Jamieson et al., 2019;)

Microplastics are found by fishes at 200-478 m depth and ingested by zooplankton in shallow waters (Zhu et al., 2019; Botterell et al., 2019). It has also been reported that they sink and accumulate in sediments causing a risk in the ecological system for benthic communities (Vianello et al., 2013; Jun Wang et al., 2019). Moreover, chronic exposure to microplastics is seldom deadly but has a bad impact on animals (Galloway et al., 2017) due to their ability to cause oxidative and pathological stresses, decrease in body immunity function, cancer, and a change in the chromosome which further leads to infertility and obesity (Sharma \& Chatterjee, 2017; Guzzetti et al., 2018).
The microplastic colors found in the fish digestive organs were transparent, black, pink, yellow, and red. The most dominant colors were transparent and black while Epinephelus fuscogutattus and Synanceia fishes mostly had pink and yellow and Epinephelus coioides were observed to have ingested mainly blue and red. The data also showed the particles were carried by water and presumed to be embedded in muddy, sandy, and rocky substrates. However, fishes were unable to differentiate between food and microplastic particles in the littoral zone. Moreover, the predominant microplastic shape was the filament type due to its elongated structure and movement in the water. Previous studies showed the proportion of fish with microplastics in their digestive tract has increased over the last 60 years (Nadal et al., 2016; Pace, 2018). Moreover, transparent and colored particles have been reported to be dominant in fish intestines (Stolte et al., 2015; Hastuti et al., 2019) while blue fibers were found in the fish larva (Steer et al., 2017).

\section{Conclusion}

The results showed microplastic particles were found in the digestive tracts of E. fuscogutattus, E. coioides, E. suillus, S. canaliculatus, Synanceia, and S. Psittacus collected in four locations in Ternate Island waters Indonesia littoral zone. The particles ingested were discovered to be fragment, film, foam, fiber, line, and pellet while the colors were transparent, black, pink, yellow, blue, and red. Therefore, further research is recommended to examine and evaluate the microplastic pollution level in deeper sea biota. The sample size should also be increased by including other fish types in future studies. For practical application, the local government needs to manage its coastal environment through a community-based approach to reduce the plastic-type pollution in the Ternate Island waters, Indonesia.

\section{Acknowledgments}

This research was funded by PNBP Universitas Negeri Malang (UM)

\section{References}

Bakir, A., Rowland, S. J., \& Thompson, R. C. (2014). Enhanced desorption of persistent organic pollutants from microplastics under simulated physiological conditions. Envirol Pol, 185, 1623.

Barnes, D. K. A., Galgani, F., Thompson, R. C., \& Barlaz, M. (2009). Accumulation and fragmentation of plastic debris in global environments. Philosophical Transactions of the Royal Society B: Biol Sci, 364 (1526), 1985-1998.

Bergmann, M., Gutow, L., \& Klages, M. (2015). Marine anthropogenic litter. In Marine Anthropogenic Litter.

Betts, K. (2008). Why small plastic particles may pose a big problem in the oceans. Enviro Sci and Tec, 42 (24), 8996.

Boerger, C. M., Lattin, G. L., Moore, S. L., \& Moore, C. J. (2010). Plastic ingestion by planktivorous fishes in the North Pacific Central Gyre. Marine Poll Bulletin, 60 (12), 2275-2278.

Botterell, Z. L. R., Beaumont, N., Dorrington, T., Steinke, M., Thompson, R. C., \& Lindeque, P. K. (2019). Bioavailability and effects of microplastics on marine zooplankton: A review. Enviro Poll, 245, 98-110. 
Cole, M., Lindeque, P., Fileman, E., Halsband, C., Goodhead, R., Moger, J., \& Galloway, T. S. (2013). Microplastic ingestion by zooplankton. Enviro Sci and Tec, 47 (12), 6646-6655.

Davison, P., \& Asch, R. G. (2011). Plastic ingestion by mesopelagic fishes in the North Pacific Subtropical Gyre. Marine Eco Progress Series, 432 (January), 173-180.

Derraik, J. G. B. (2002). The pollution of the marine environment by plastic debris: A review. Marine Poll Bulletin, 44 (9), 842852.

Eriksson, C., \& Burton, H. (2003). Origins and Biological Accumulation of Small Plastic Particles in Fur Seals from Macquarie Island. Ambio, 32 (6), 380-384.

Farrell, P., \& Nelson, K. (2013). Trophic level transfer of microplastic: Mytilus edulis (L.) to Carcinus maenas (L.). Enviro Poll J, 177, 1-3.

Firdaus, M., Trihadiningrum, Y., \& Lestari, P. (2020) Microplastic pollution in the sediment of Jagir Estuary, Surabaya City, Indonesia. Marine Poll Bulleti, 150 (November), 110790.

Free, C. M., Jensen, O. P., Mason, S. A., Eriksen, M., Williamson, N. J., \& Boldgiv, B. (2014). High-levels of microplastic pollution in a large, remote, mountain lake. Marine Poll Bulleti 85 (1), 156163.

Galloway, T. S., Cole, M., \& Lewis, C. (2017). Interactions of microplastic debris throughout the marine ecosystem. Nature Eco and Evo, 1 (5), 1-8.

Goldstein, M. C., \& Goodwin, D. S. (2013). Gooseneck barnacles (Lepas spp.) ingest microplastic debris in the north Pacific subtropical gyre. PeerJ, 2013 1, 1-17.

Guzzetti, E., Sureda, A., Tejada, S., \& Faggio, C. (2018). Microplastic in marine organism: Environmental and toxicological effects. Enviro Toxic and Pharma, 64, 164-171.

Handyman, D. I. W., Purba, N. P., Pranowo, W. S., Harahap, S. A., Dante, I. F., \& Yuliadi, L. P. S. (2019). Microplastics patch based on hydrodynamic modeling in the north Indramayu, Java sea. Polish J Enviro Studies, 28 (1), 135-142.

Hastuti, A. R., Lumbanbatu, D. T. F., \& Wardiatno, Y. (2019) The presence of microplastics in the digestive tract of commercial fishes off pantai Indah Kapuk coast, Jakarta, Indonesia. Biodiversitas, 20 (5), 1233-1242.

Hidalgo-Ruz, V., Gutow, L., Thompson, R. C., \& Thiel, M. (2012). Microplastics in the marine environment: A review of the methods used for identification and quantification. Enviro Sci and Tec, 46 (6), 3060-3075.

Ismail, M. R., Lewaru, M. W., \& Prihadi, D. J. (2019). Microplastics Ingestion by Fish in The Pangandaran Bay, Indonesia. World News of Natural Sci, 23 (8), 173-181.

Ivleva, N. P., Wiesheu, A. C., \& Niessner, R. (2017). Microplastic in Aquatic Ecosystems. Angewandte Chemie International Edition, 56 (7), 1720-1739.

Jabeen, K., Su, L., Li, J., Yang, D., Tong, C., Mu, J., \& Shi, H. (2017). Microplastics and mesoplastics in fish from coastal and fresh waters of China. Envirol Poll Sci. 221, 141-149.

Jambeck, J. R., Ji, Q., Zhang, Y.-G., Liu, D., Grossnickle, D. M., \& Luo, Z.-X. (2015). Plastic waste inputs from land into the ocean. Sci J, 347 (6223), 764-768.

Jamieson, A. J., Brooks, L. S. R., Reid, W. D. K., Piertney, S. B. Narayanaswamy, B. E., \& Linley, T. D. (2019). Microplastics and synthetic particles ingested by deep-sea amphipods in six of the deepest marine ecosystems on Earth. R S Open Sci 6 (2).

Law, K., \& Thompson, R. C. (2014). Microplastics in the seas Concern is rising about widespread contamination of the marine environment by microplastics. In Sci. (Vol. 345, Issue 6193, pp. 144-145)
Li, J., Qu, X., Su, L., Zhang, W., Yang, D., Kolandhasamy, P., Li, D., \& Shi, H. (2016). Microplastics in mussels along the coastal waters of China. Enviro Poll, 214, 177-184.

Lie, S., Suyoko, A., Effendi, A. R., Ahmada, B., Hadid, N. I., Rahmasari, N., \& Reza, A. (2018). Measurement of microplastic density in the Karimunjawa National Park, Central Java , Indonesia. 2 (2), 54-58.

Lusher, A. L., Burke, A., O’Connor, I., \& Officer, R. (2014). Microplastic pollution in the Northeast Atlantic Ocean: Validated and opportunistic sampling. Marine Poll Bulletin,, 88 (1-2), 325333.

Manalu, A. A., Hariyadi, S., \& Wardiatno, Y. (2017). Microplastics abundance in coastal sediments of Jakarta Bay, Indonesia. AACL Bioflux, 10 (5), 1164-1173.

Murray, F., \& Cowie, P. R. (2011). Plastic contamination in the decapod crustacean Nephrops norvegicus (Linnaeus, 1758). Marine Poll Bulletin, 62 (6), 1207-1217.

Nadal, M. A., Alomar, C., \& Deudero, S. (2016). High levels of microplastic ingestion by the semipelagic fish bogue Boops boops (L.) around the Balearic Islands. Enviro Poll, 214, 517-523.

Ng, K. L., \& Obbard, J. P. (2006). Prevalence of microplastics in Singapore's coastal marine environment. Marine Poll Bulletin, 52 (7), 761-767.

Pace, E. Di. (2018). Proceedings of the International Conference on Microplastic Pollution in the Mediterranean Sea. International Conference on Microplastic Pollution in the Mediterranean Sea, 22 (5), 238.

Rochman, C. M., Hoh, E., Kurobe, T., \& Teh, S. J. (2013). Ingested plastic transfers hazardous chemicals to fish and induces hepatic stress. Scientific Reports, 3, 1-7.

Romeo, T., Pietro, B., Pedà, C., Consoli, P., Andaloro, F., \& Fossi, M. C. (2015). First evidence of presence of plastic debris in stomach of large pelagic fish in the Mediterranean Sea. Marine Poll Bulletin,, 95 (1), 358-361.

https://doi.org/10.1016/j.marpolbul.2015.04.048

Rowland, S. J., Galloway, T. S., \& Galloway, T. S. (2016). Potential for Plastics to Transport Hydrophobic Contaminants Potential for Plastics to Transport Hydrophobic Contaminants. ACS Publications, 41; 7759-7764.

Ryan, P. G., Moore, C. J., Van Franeker, J. A., \& Moloney, C. L. (2009). Monitoring the abundance of plastic debris in the marine environment. Philosophical Transactions of the Royal Society B: Biol Sci, 364 (1526), 1999-2012.

Setälä, O., Norkko, J., \& Lehtiniemi, M. (2016). Feeding type affects microplastic ingestion in a coastal invertebrate community. Marine Poll Bulletin, 102 (1), 95-101.

Sharma, S., \& Chatterjee, S. (2017). Microplastic pollution, a threat to marine ecosystem and human health: a short review. Enviro Sci and Pollution Research, 24 (27), 21530-21547.

Steer, M., Cole, M., Thompson, R. C., \& Lindeque, P. K. (2017). Microplastic ingestion in fish larvae in the western English Channel. Enviro Poll, 226, 250-259.

tolte, A., Forster, S., Gerdts, G., \& Schubert, H. (2015). Microplastic concentrations in beach sediments along the German Baltic coast. Marine Poll Bulletin, 99 (1-2), 216-229.

Syakti, A. D., Bouhroum, R., Hidayati, N. V., Koenawan, C. J., Boulkamh, A., Sulistyo, I., Lebarillier, S., Akhlus, S., Doumenq, P., \& Wong-Wah-Chung, P. (2017). Beach macro-litter monitoring and floating microplastic in a coastal area of Indonesia. Marine Poll Bulletin, 122 (1-2), 217-225.

Syakti, A. D., Hidayati, N. V., Jaya, Y. V., Siregar, S. H., Yude, R., Suhendy, Asia, L., Wong-Wah-Chung, P., \& Doumenq, P. (2018). Simultaneous grading of microplastic size sampling in the 
Small Islands of Bintan water, Indonesia. Marine Poll Bulletin, 137 (November), 593-600.

Tahir, A., Samawi, M. F., Sari, K., Hidayat, R., Nimzet, R., Wicaksono, E. A., Asrul, L., \& Werorilangi, S. (2019). Studies on microplastic contamination in seagrass beds at Spermonde Archipelago of Makassar Strait, Indonesia. Physics J: Conference Series, 1341 (2).

Van Cauwenberghe, L., Vanreusel, A., Mees, J., \& Janssen, C. R. (2013). Microplastic pollution in deep-sea sediments. Enviro= Poll, 182, 495-499.

Vianello, A., Boldrin, A., Guerriero, P., Moschino, V., Rella, R., Sturaro, A., \& Da Ros, L. (2013). Microplastic particles in sediments of Lagoon of Venice, Italy: First observations on occurrence, spatial patterns and identification. Estuarine, $C$ and Shelf Sci, 130, 54-61.
Wagner, M., \& Lambert, S. (2018). Freshwater Microplastics The Handbook of Environmental Chemistry 58 (p. 302).

Wang, Jun, Wang, M., Ru, S., \& Liu, X. (2019). High levels of microplastic pollution in the sediments and benthic organisms of the South Yellow Sea, China. Sci of the Total Envir, 651, 16611669.

Wang, Jundong, Tan, Z., Peng, J., Qiu, Q., \& Li, M. (2016). The behaviors of microplastics in the marine environment. Marine Enviro Research, 113, 7-17.

Wick, A. F., Daniels, W. L., Orndorff, Z. W., \& Alley, M. M. (2013). Organic matter accumulation post-mineral sands mining. Soil Use and Management, 29 (3), 354-364.

Zhu, L., Wang, H., Chen, B., Sun, X., Qu, K., \& Xia, B. (2019). Microplastic ingestion in deep-sea fish from the South China Sea. Sci of the Total Envior, 677, 493-501. 